\title{
Assessing Quality of Reclaimed Urban Wastewater from Algarrobo Municipality to Be Used for Irrigation
}

\author{
Desireé Muñoz-Sánchez, Veronika Bogodist, Vicente Manuel García-Cañizares, David Frías-Gil, \\ María Remedios López-Díaz, Emilio Jaime-Fernández, María Remedios Romero-Aranda*
}

Department of Plant Breeding and Biotechnology, IHSM-La Mayora, CSIC, Algarrobo, Spain

Email: *rromero@eelm.csic.es

How to cite this paper: Muñoz-Sánchez, D., Bogodist, V., García-Cañizares, V.M., Frías-Gil, D., López-Díaz, M.R, Jaime-Fernández, E. and Romero-Aranda, M.R. (2018) Assessing Quality of Reclaimed Urban Wastewater from Algarrobo Municipality to Be Used for Irrigation. Journal of Water Resource and Protection, 10, 1090-1105. https://doi.org/10.4236/jwarp.2018.1011064

Received: September 27, 2018 Accepted: November 12, 2018 Published: November 15, 2018

Copyright $\odot 2018$ by authors and Scientific Research Publishing Inc. This work is licensed under the Creative Commons Attribution International License (CC BY 4.0).

http://creativecommons.org/licenses/by/4.0/

\begin{abstract}
In the European Mediterranean area, the lack of available water resources had led to consider the reclaimed urban waters as an integral part of water resources. Reclaimed urban waters could mitigate water shortage, support agriculture sector and protect rivers and groundwater resources. This work is focused on the evaluation of reclaimed urban water (RW) from Algarrobo municipality, which is located in the Málaga province in the Mediterranean coast at South-East of Spain. Wastewater in the municipal waste water treatment plant, was treated by a membrane bioreactor (MBR) as a tertiary treatment. The main goal of this work was to determine the composition of RW to be compared with fresh local water (LW) from the Algarrobo River, in order to evaluate its suitability for irrigation. Electrical conductivity (EC), $\mathrm{pH}$, sodium absorption ratio (SAR), and mineral content were weekly measured from September 2017 until June 2018. Assessment of RW quality was carried out considering the limit values for each parameter as stated by the current Spanish legislation RD 1620/2007 for reuse of reclaimed water and European Directive for water reuse (EU 91/271/EEC, Annex I). The MBR facility was also focused on preserving essential minerals for plant nutrition to use them for crop fertilization instead of commercial fertilizers. The average content of nitrogen, phosphorous and potassium were, respectively, $72 \%, 65 \%$ and $46 \%$ of the amount needed for the Hoagland $1 / 4$ strength solution that was used in this study for irrigation of tomato, avocado and mango crops. From this study it appears that it is possible using membrane technology, to treat urban wastewater in order to supply a good quality of water for irrigation. Water analysis has also proved MBR to be efficient for removal of microbiological pollutants, inorganic compounds, some trace elements and heavy metals. The assessment of RW shows that the evaluated parameters of water-quality are
\end{abstract}


within the range of values stated by Spanish legislation and the current European Directive for secure use of reclaimed water for irrigation.

\section{Keywords}

Reclaimed Urban Water, MBR, Electrical Conductivity, SAR, Nutrients, Trace Elements, Heavy Metals

\section{Introduction}

Water stress due to climate change and the overexploitation of water resources are two of the most serious and widespread environmental problems worldwide [1]. One fifth of the Mediterranean population constantly suffers from a shortage of water, and during summer lack of available water affects up to $50 \%$ of population in Mediterranean region, which includes Spain, Portugal, Italy, Cyprus, Greece, Malta and Southern France [2]. Reclaimed urban water (RW) is the domestic wastewater that has received tertiary treatment and disinfection. The application of RW is of great importance to ease the water shortage and reduce further pollution by sewage. The use of RW has become a common and international trend as an unconventional supply for rivers with water shortages and for agricultural purposes [3]. Although RW may meet certain water quality standards, it is still urban sewage and carries some risk. However, current water reclamation technology can ensure $>99.99 \%$ pathogen removal [4]; thus, the likelihood of human disease occurring through the use of RW is extremely low.

In the world, $60 \%$ to $90 \%$ of available water is used for agricultural purposes [5]. Growing population is increasingly competing with commercial and agricultural uses of limited freshwater supplies. Thus, agriculture may have to rely on using RW to meet crop irrigation needs.

Membrane reclamation procedures based on ultrafiltration and nanofiltration have been recognized as one of the most efficient treatment methods for the production of good quality water, even for drinking water [6] [7] [8]. Yet, the performance of these techniques is linked to the intrinsic properties of the membranes [9] and the choices of the best membrane which depends on the quality of water to be treated and the operational conditions [6] [10].

In the province of Malaga RW is not yet used for agricultural irrigation. Using RW for irrigation purposes, in addition to savings of freshwater supplies, can partially supply some nutrients, particularly nitrogen, phosphorous, and potassium, which are the primary nutrients needed to stimulate yield and quality of agricultural crops [11]. Considering that RW may contain a high content of essential nutrients for plants, the use of this water to elaborate the irrigation solution could significantly reduce the application of standard commercial fertilizers and its associated costs. Irrigation with RW has also been shown to improve soil physical properties, including aggregate stability and water infiltration rates [12]. 
However, there are concerns about the impact of the quality of the RW on crops, soils, and irrigation systems. Because little if any salt is removed during conventional treatment, urban wastewater can contain salt concentrations high enough to cause concern to growers. Salt accumulation in soils irrigated with reclaimed waters can result in plant growth inhibition due to increasing osmotic stress and ion toxicity and hence decreasing yield and harvest quality [13] [14] [15]. Therefore, the study of RW quality for irrigation purpose has a high practical relevance for growers in Málaga province.

The aim of this study was to evaluate the quality of reclaimed water from a membrane bioreactor system (MBR), while keeping primary nutrients for crops development and coping with demands imposed by the Spanish legislation for water reuse in agriculture. The specific objectives were to determine in the RW the concentrations of saline ions (chloride and sodium), primary plant nutrients (nitrogen, phosphorous and potassium), trace elements, and heavy metals to be compared with recorded values on the fresh local water from Algarrobo River, which is currently used for irrigation by local growers. Documenting the quality of RW will be of significant benefit not only to guarantee the safe use of reclaimed water and the sustainability of agricultural practices in Algarrobo municipality, but also to assure for the future the environmental protection of Algarrobo River.

\section{Material and Methods}

\subsection{Study Area}

The membrane reactor system (MBR) is placed at the municipal wastewater treatment plant (MWWTP) of Algarrobo municipality, province of Málaga (Spain), longitude $36.7^{\circ} \mathrm{N}$, latitude $4.6^{\circ} \mathrm{E} ; 20 \mathrm{~m}$. Figure 1 shows the map of experimental site where the present study was developed. Algarrobo municipality is composed of several small towns-Algarrobo, Algarrobo Costa, Mezquitilla and Trayamar, with a joint population of approximately 5000 people. The total area is $9.73 \mathrm{~km}^{2}$ and it has access to the Mediterranean Sea on the south. The main economic activities of Algarrobo municipality are agriculture, fishing and tourism.

\subsection{Pilot Membrane Bioreactor}

The wastewater treatment facility consists in a membrane bioreactor system (MBR) composed of a multi parameter monitoring and controlling units designed and maintained by Bioazul S.L. Málaga, Spain. Before entering the MBR, municipal wastewater passes in the waste water municipal treatment plant through screening and grit removal. Then, wastewater passes through a second screening to remove particles with diameter more than $2 \mathrm{~mm}$. The two-step screening system ensures that inlet wastewater does not contain particles, which can lead to the clogging and the destruction of the MBR. In the MBR, the organic matter is treated by means of a biological decomposition. The main 


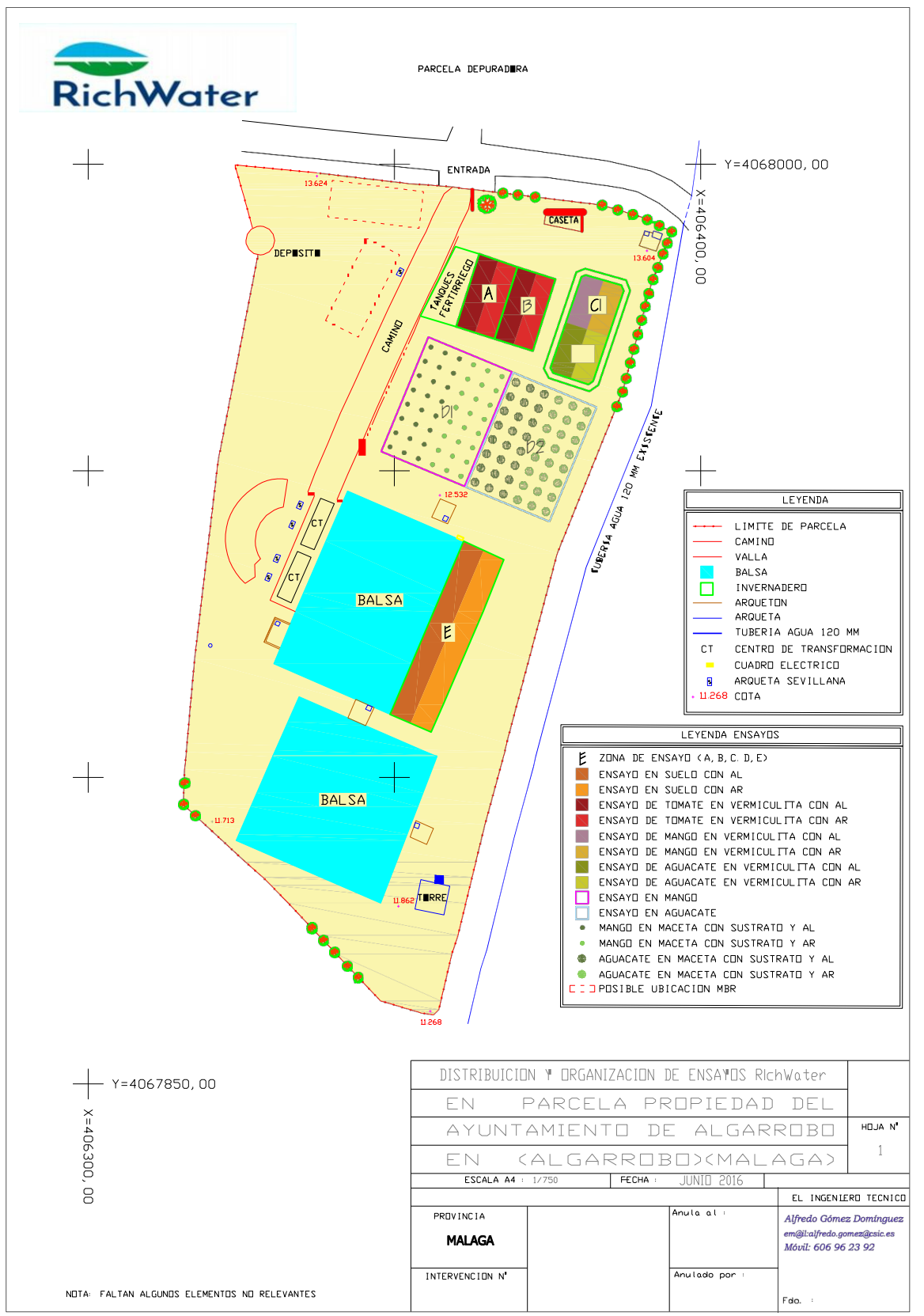

Figure 1. Map of the experimental site where the present study was developed.

difference of this process as compared to the conventional activated sludge removal is the way of treating nutrients. The aim is to keep nitrates $\left(\mathrm{NO}_{3}^{-}\right)$in the water stream instead of removing them. Therefore, only nitrification by oxidation of ammonium $\left(\mathrm{NH}_{4}^{+}\right)$takes place, while convenient AST includes both nitrification and denitrification processes. Phosphorous $(\mathrm{P})$ and potassium $(\mathrm{K})$ are not degraded either. After sludge removal, treated wastewater flows to the membrane reactor, where pathogens are removed and their contamination in the water stream is controlled. The type of the membrane is a flat sheet ultrafiltration cassette composed of 26 active filter plates, 2 protective plates-all made of polypropylene, and laser welded membrane made of polyether sulfone (cassette 
filter model MCXS2, Newterra, Spain). The size of pore is $0.04 \mu \mathrm{m}$, which corresponds to the ultrafiltration. The filtration pressure is between $0.1-0.25 \mathrm{bar}$ [16]. The pilot treatment plant applies a ultra-violet purification method using a mercury vapor low pressure UV-lamp (MINI-65W/4P) that disinfects water from microorganisms.

\subsection{Water Sampling and Analysis}

Quality parameters of reclaimed urban water (RW) from Algarrobo municipality were compared with those of fresh local water (LW) pumped from the Algarrobo River, which supplies a large part of the water used by Community of growers of the municipality of Algarrobo.

The choice of water parameters was based on the Spanish legislation concerning quality of the reclaimed water for agricultural irrigation (RD 1620/2007, Annex II, type of water 2.3) [17] and the European Directive with specific rules about the quality of effluent after treatment (EU 91/271/EEC, Annex I) [18]. The measurement also included nitrogen, phosphorous, potassium, calcium, magnesium and sulfur, because they are essential elements for crops development.

The collections of water samples were carried out weekly from September 2017 to June 2018. Over this time, a total of 50 and 42 sampling dates were evaluated for RW and LW, respectively. Water samples from each water source and date were collected in sterilized $250 \mathrm{ml}$ bottles, transported in an ice chest to the laboratory and stored at $5^{\circ} \mathrm{C}$ before being processed for physico-chemical analyses.

Microbiological analysis was developed by a private certificated laboratory (NeoIntegra XXI S.L., Málaga, Spain). Intestinal Nematodes in water samples were measured by Bailenger method. Legionella spp. was analyzed according to the method of ISO 11731. Total coliforms and Escherichia coli concentrations were quantified via membrane filtration on MI agar BBLTM (Becton Dickinson) using EPA method 1604 [19]. Intestinal nematodes in water samples were measured following Silva et al. [20].

Suspended solids were determined using a PC-2700 meter (Eutech Instruments, Singapore). pH was measured with a Crison $507 \mathrm{pH}$-meter (Crison Instruments S.A., Barcelona, Spain). Electrical conductivity was measured with an electrical conductivity meter (PCE, model CM-4), and turbidity was measured with a Dinko-D-110 (Dinko Instruments S.A., Barcelona, Spain) turbidity meter. Samples were also analyzed for phosphorous $(\mathrm{P})$ potassium $(\mathrm{K})$, calcium $(\mathrm{Ca})$, magnesium $(\mathrm{Mg})$, sulfur $(\mathrm{S})$, iron $(\mathrm{Fe})$, zinc $(\mathrm{Zn})$, manganese $(\mathrm{Mn})$, copper $(\mathrm{Cu})$, boron $(\mathrm{B})$, aluminum $(\mathrm{Al})$, molybdenum $(\mathrm{Mo})$, and sodium $(\mathrm{Na})$ using an inductively coupled plasma-optical emission spectrometer. These analyses were conducted by the Ionomics Service CEBAS-CSIC, using a plasma-optical emission spectrometer (ICP-OES, Icap 6500 duo thermo) shown in Figure 2. Preserved samples were analyzed for chloride $\left(\mathrm{Cl}^{-}\right)$and ammonium-N $\left(\mathrm{NH}_{4}-\mathrm{N}\right)$ and nitrate/nitrite- $\mathrm{N}\left(\mathrm{NO}_{\mathrm{x}}-\mathrm{N} ; \mathrm{NO}_{2}^{-}+\mathrm{NO}_{3}^{-}\right)$using an Automated Discrete Analyzer (AQ2+, Seal Analytical Inc., Mequon, WI). 


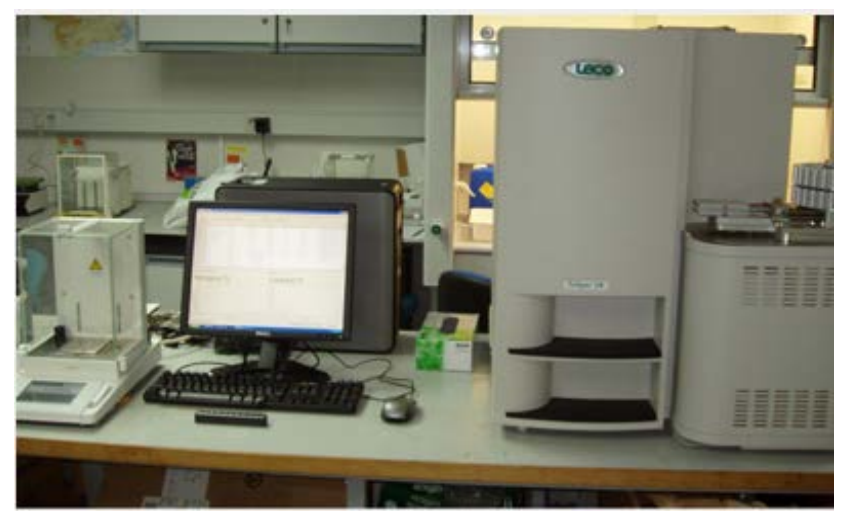

Figure 2. Mineral analyses were conducted by the ionomics service of CEBAS-CSIC, using a plasma-optical emission spectrometer (ICP-OES, Icap 6500 duo thermo).

\section{Results and Discussion}

\subsection{Basic Properties of Water for Irrigation}

Assessment of RW quality in this study was carried out considering the limit values for each parameter as stated by the Spanish legislation for reuse of reclaimed water, RD 1620/2007 [17], the European directive for water reuse (91/271/EEC) [18] and the international World Health Organization guide lines (WHO) [21]. According to RD 1620/2007 [17], the analysed wastewater in this study correspond to level 2.3, because this water is used for localized drip irrigation of woody crops without contact with fruits consumed by humans, such as mango and avocado, and for drip irrigation of greenhouse crops without direct contact with edible harvest such as tomato.

The MBR treatment focused on removal dangerous microbiological contamination. According to the European Directive 91/271/EEC the limit concentrations for 5-day Biochemical Oxygen Demand $\left(\mathrm{BOD}_{5}\right)$, and Chemical Oxygen Demand (COD) are $25 \mathrm{mg} / \mathrm{L} \mathrm{O}_{2}$, and $125 \mathrm{mg} / \mathrm{L} \mathrm{O}_{2}$, respectively [18]. As showed in Figure 3(a), the RW presented $\mathrm{BOD}_{5}$ below the limit stated by the EU Directive previously mentioned. COD values were also below the values imposed by the European Directive (Figure 3(b)). The days were these values were above the limit was due to some membranes were broken by the large amount of sand that contained the starting water from the sewer network of the municipality of Algarrobo.

Recorded data show that CFU of Escherichia coli in RW presented a maximum value of $70 \mathrm{CFU} / 100 \mathrm{~mL}$, which is lower than the limit of $100 \mathrm{CFU} / 100 \mathrm{~mL}$ stated by the current Spanish and European legislation (Table 1). Intestinal Nematodes and Legionella spp. were not detected along all the period of study with small exception: in the week 8, Legionella spp. was above the limit of $100 \mathrm{CFU} / \mathrm{L}$, reaching $300 \mathrm{CFU} / \mathrm{L}$. The value of Intestinal Nematodes was once above the limit of $1 \mathrm{egg} / 10 \mathrm{~L}$ in the week 19 , reaching the value of $5 \mathrm{eggs} / 10 \mathrm{~L}$.

Physicochemical parameters for RW assessment included suspended solids (SS) and turbidity (Table 1). The value of SS in RW was changing along the 


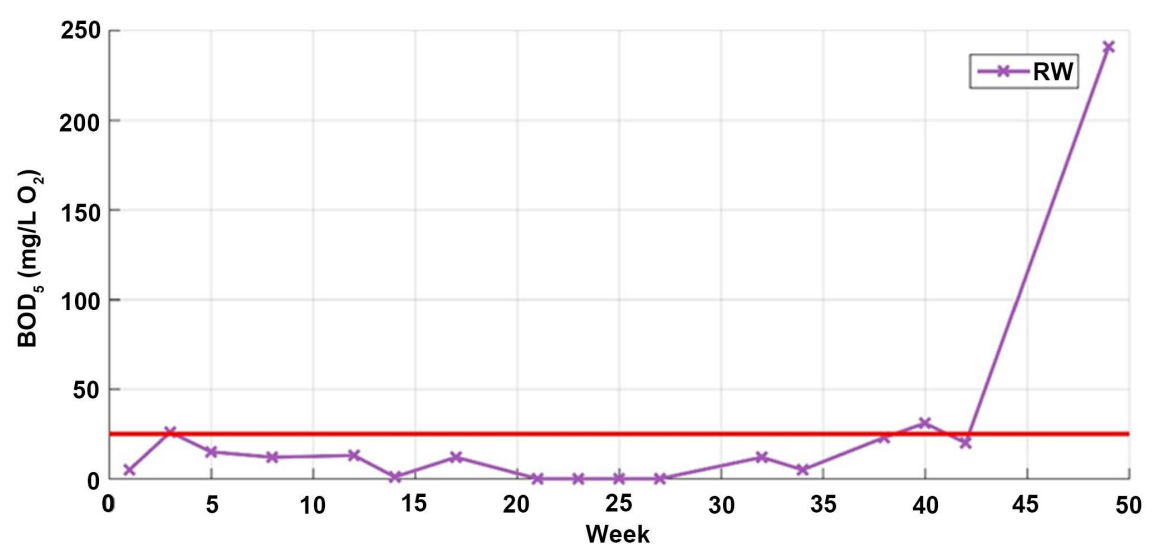

(a)

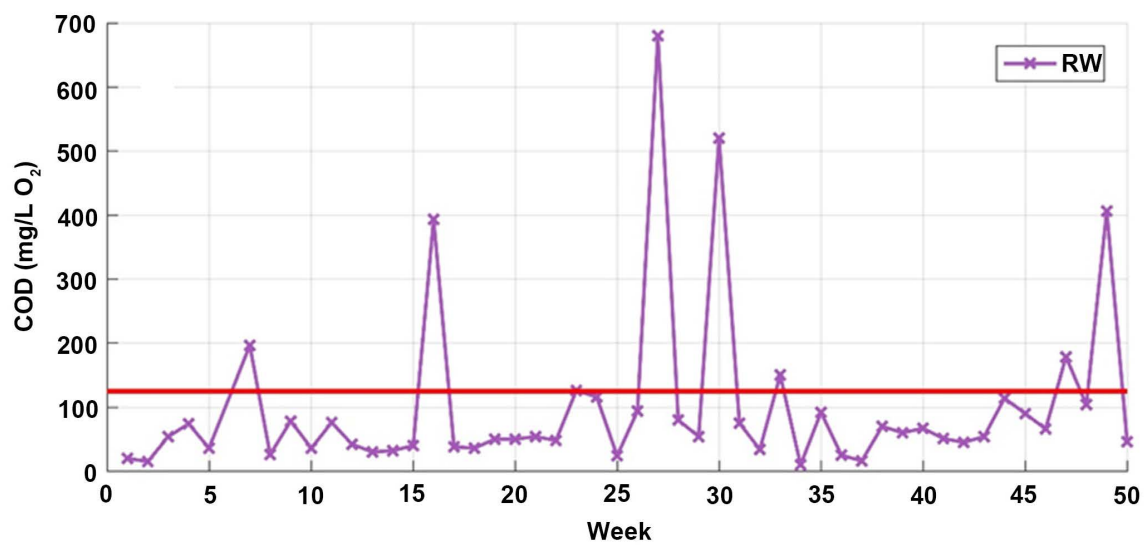

(b)

Figure 3. Time evolution of 5-days Biochemical Oxygen Demand $\left(\mathrm{BOD}_{5},(\mathrm{a})\right)$, and Chemical Oxygen Demand (COD, (b)) of reclaimed urban water (RW) from the MBR plant. Red lines show the limit values stated by the current Spanish legislation RD 1620/2007, and by the European Directive 91/271/EEC.

Table 1. Microbiological, physical and chemical properties of fresh local water from Algarrobo River (LW) and reclaimed urban water from the MBR plant (RW), recorded in two different dates. Assessment of RW quality in this study was carried out considering the limit values for each parameter as stated by the Spanish legislation for reuse of reclaimed water (RD 1620/2007).

\begin{tabular}{|c|c|c|c|c|c|}
\hline & \multirow{2}{*}{$\begin{array}{c}\text { Reference } \\
\text { RD 1620/2007 }\end{array}$} & \multicolumn{2}{|c|}{$02 / 01 / 2018$} & \multicolumn{2}{|c|}{$02 / 05 / 2018$} \\
\hline & & LW & RW & LW & RW \\
\hline E. coli (UFC/100ml) & 100 & 0 & 79 & 70 & 1 \\
\hline Nematodes (eggs/10L) & 1 & 0 & 0 & 0 & 0 \\
\hline Legionella spp (UFC/L) & 100 & 0 & 0 & 0 & 0 \\
\hline Suspended Solids (mg/L) & 20 & 3 & 17 & 2 & 4 \\
\hline Turbidity (NTU/100ml) & 10 & 4 & 6 & 2 & 3 \\
\hline Chemical Oxygen Demand $\left(\mathrm{mgO}_{2} / \mathrm{L}\right)$ & 125 & 9 & 24 & 15 & 45 \\
\hline Biochemical Oxygen Demand $\left(\mathrm{mgO}_{2} / \mathrm{L}\right)$ & 25 & 0 & 0 & 0 & 20 \\
\hline
\end{tabular}


period of study and rose above the limit of $35 \mathrm{mg} / \mathrm{L}$ seven times. The maximum amount of SS in RW was recorded on week 26 (107 mg/L, January 2018). Other two high values were recorded in October 2017 and June 2018 (weeks 15 and 48), with values of $85 \mathrm{mg} / \mathrm{L}$ and $67 \mathrm{mg} / \mathrm{L}$, respectively. The content of SS in LW was always below the limit stated by the current legislation $(20 \mathrm{mg} / \mathrm{L})$. Turbidity limit according to current legislation is $10 \mathrm{NTU} / 100 \mathrm{~mL}$. Only in weeks 37 and 40 (end of March 2018 and middle of April 2018) and in the week 49 (June 12, 2018) were recorded in RW turbidity values higher than 10 NTU/100 mL.

The $\mathrm{pH}$ is an important characteristic of reclaimed water when considering its reuse for irrigation. It is widely documented that the ideal range of $\mathrm{pH}$ values in the irrigation water should be between 5.5 and 6.5 as this provides a balance of availability between the essential plant nutrients [22]. Figure 4 shows the time evolution of $\mathrm{pH}$ during this study. The $\mathrm{pH}$ of both $\mathrm{RW}$ and LW was slightly alkaline (Figure 4(a)). However, the measured values of $\mathrm{pH}$ were within the EPA recommended range of $\mathrm{pH}(6-9)$ for water reuse for irrigation [23].

Electrical conductivity (EC) is directly related to the concentration of dissolved ions in the water, but the relationship may not be constant [24]. The EC values of the RW exceeded the limit of $3 \mathrm{dS} / \mathrm{m}$ two times at the beginning of the study: week 4 (August 2017) and week 8 (September 2017) with values $4.68 \mathrm{dS} / \mathrm{m}$ and $5.32 \mathrm{dS} / \mathrm{m}$, respectively (Figure $4(\mathrm{~b})$ ). The range of EC values for the rest of dates were well below the EPA limits of $<3.0 \mathrm{dS} / \mathrm{m}$ [23]. The high EC values recorded in these weeks should be related to the renovation works that were being carried out during these dates in the fishing port of Caleta de Vélez, which is near to Algarrobo municipality.

\subsection{Concentration of Salinity-Related Ions in RW and LW}

High concentration of soluble salts in the irrigation water limits plant development and reduce yield and harvest quality [25] [26]. To provide more detailed information about salinity in the RW, concentration of calcium $\left(\mathrm{Ca}^{2+}\right)$, magnesium $\left(\mathrm{Mg}^{2+}\right)$, sulfate $\left(\mathrm{SO}_{4}^{2-}\right)$, chloride $\left(\mathrm{Cl}^{-}\right)$, and sodium $\left(\mathrm{Na}^{+}\right)$, were recorded weekly along the entire period of this study. Values recorded in RW were compared with recorded values in LW and analyzed with respect to the limit values given by RD 1620/2007 [17] and by WHO guidelines for the water quality for irrigation [21].

The limit values of $\mathrm{Cl}^{-}(500 \mathrm{~m} / \mathrm{L})$ and $\mathrm{Na}^{+}(900 \mathrm{mg} / \mathrm{L})$ in the irrigation water established by WHO and RD 1620/2007 must be strongly considered due to the toxic effects of these ions on photosynthesis [13] [14], especially for mango and avocado crops, which are extremely sensitive to foliar salt accumulation. Figure 5 shows the time evolution of $\mathrm{Cl}^{-}$and $\mathrm{Na}^{+}$in both types of water. At the beginning of this study, the extremely high values of $\mathrm{Cl}^{-}$and $\mathrm{Na}^{+}$concentration in the RW (week 4), should be related to the renovation works that were being carried out during this time in the fishing port of Caleta de Velez. Later on, high $\mathrm{Cl}^{-}$ values recorded in RW should be related to the fact that some membranes were 


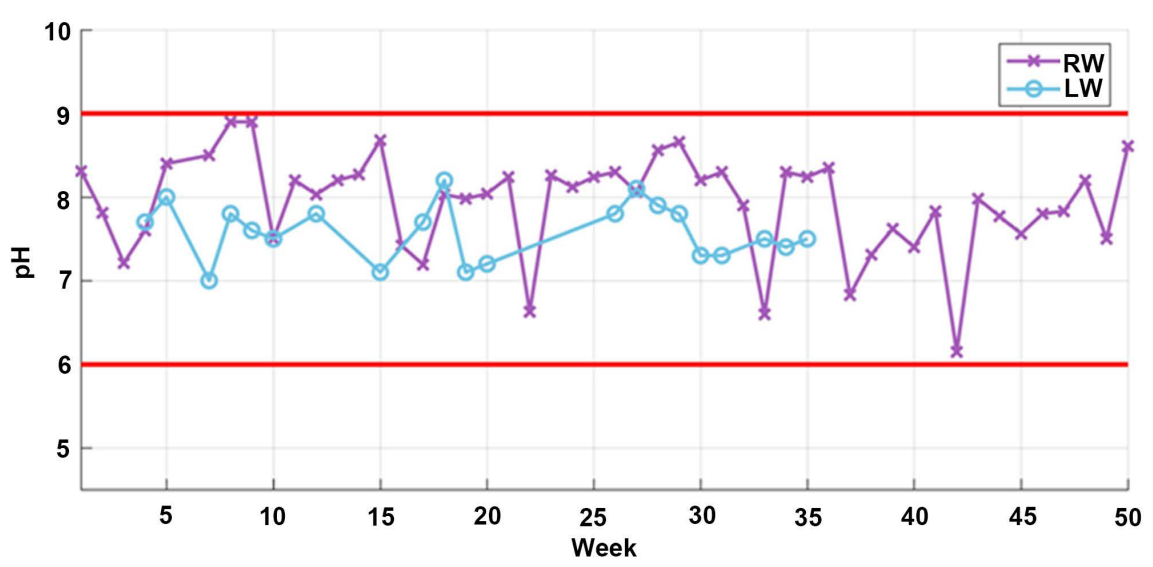

(a)

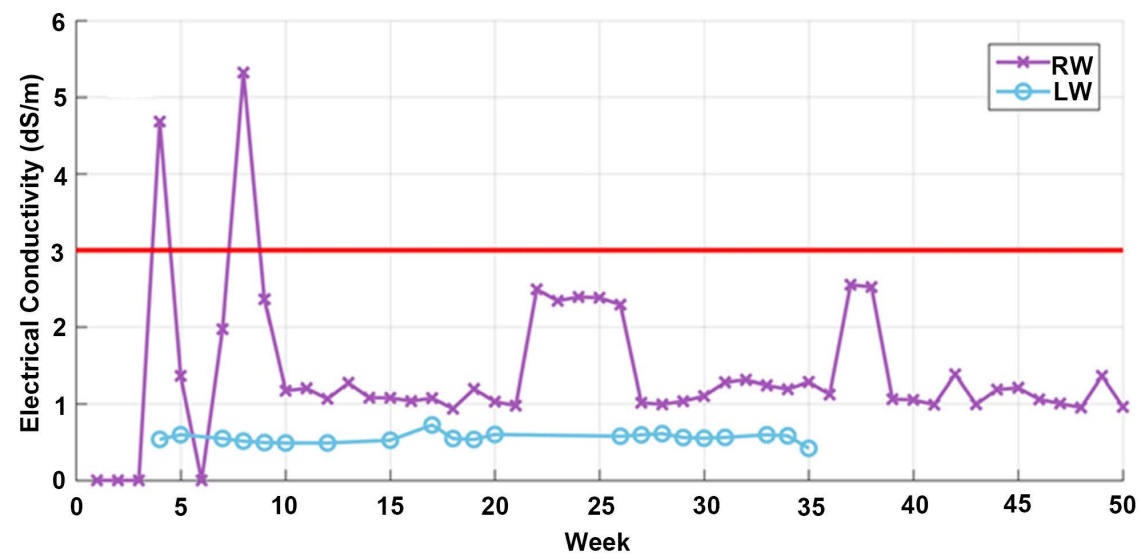

(b)

Figure 4. Time evolution of the $\mathrm{pH}$ (a) and electrical conductivity (b) recorded in fresh local water (LW) from Algarrobo River and in reclaimed urban water (RW) from the MBR plant. Red lines show the limit values stated by the current Spanish legislation RD 1620/2007, and by the European Directive 91/271/EEC.

broken by the large amount of sand that contained the starting water from the sewer network of the municipality of Algarrobo.

An important parameter of quality water for irrigation is the sodium adsorption ratio (SAR) also named as sodicity, which is a definition for the presence of high proportion of $\mathrm{Na}^{+}$compared to the amount of $\mathrm{Ca}^{2+}$ and $\mathrm{Mg}^{2+}$ (Equation (1)). $\mathrm{Na}^{+}$in the irrigation water determines the stability of the soil structure, while $\mathrm{Ca}^{2+}$ and $\mathrm{Mg}^{2+}$ contribute in unifying the effect of the clay sheets [27] [28].

$$
S A R=\frac{\mathrm{Na}^{+}}{\sqrt{\frac{1}{2} *\left(\mathrm{Ca}^{2+}+\mathrm{Mg}^{2+}\right)}}
$$

Values of SAR recorded in the present study were below the limit value (15 meq/L) given by FAO paper 29 [29] and below the striker limit value (6 meq/L) established in the Spanish RD 1620/2007 [17] (Figure 6).

Between the other mineral analyzed, the concentration of $\mathrm{Ca}^{2+}$ registered in the two types of water (RW and LW) was in the range of $50-140 \mathrm{mg} / \mathrm{L}$. These 


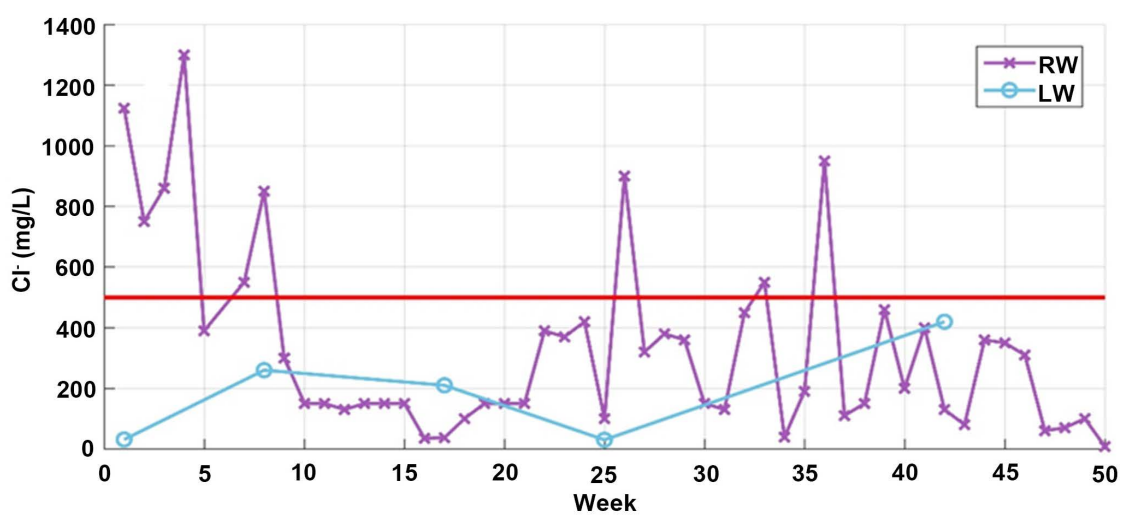

(a)

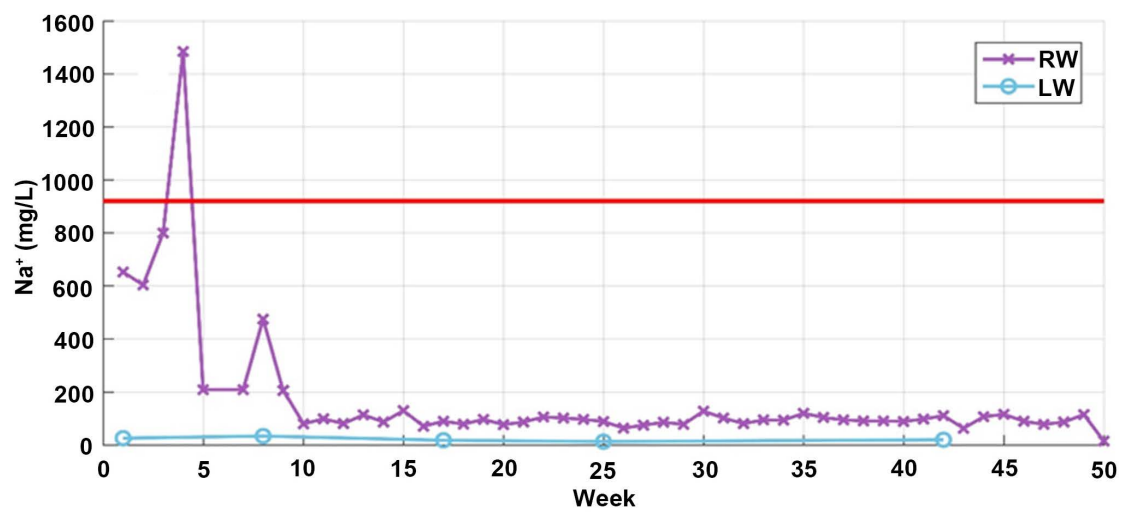

(b)

Figure 5. Time evolution of chloride (a) and sodium (b) ions recorded in fresh local water (LW) from Algarrobo River and in reclaimed urban water (RW) from the MBR plant. Red lines show the limit values stated by the current Spanish legislation RD 1620/2007, and by the European Directive 91/271/EEC.

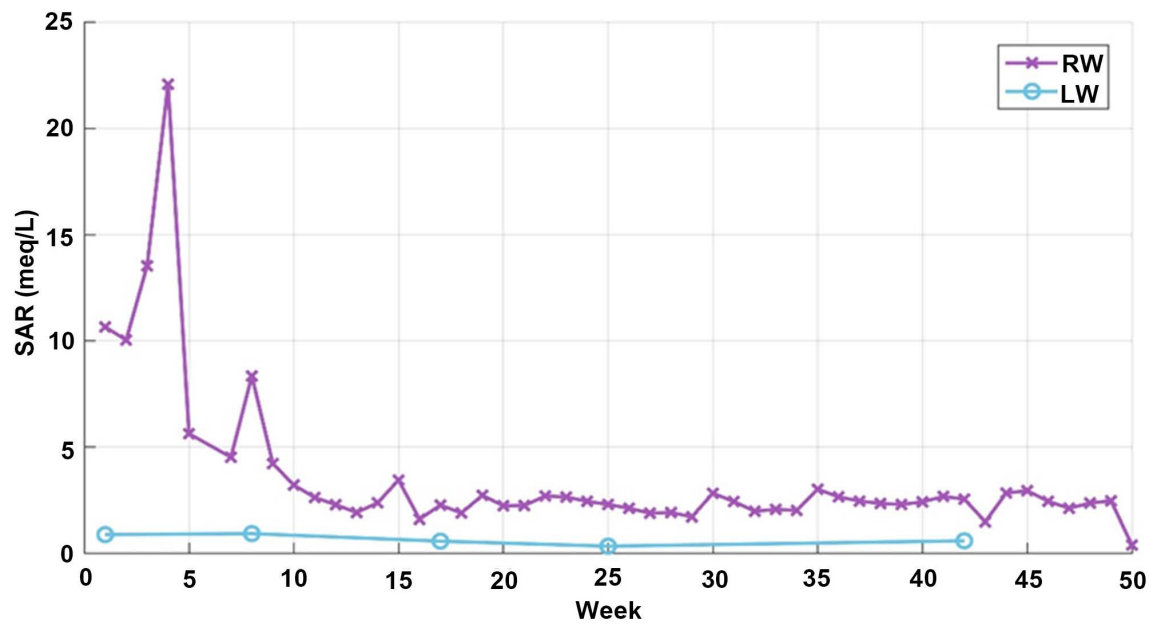

Figure 6. Time evolution of sodium adsorption ratio (SAR) recorded in fresh local water (LW) from Algarrobo River and in reclaimed urban water (RW) from the MBR plant.

values are much lower than the limit value $(400 \mathrm{mg} / \mathrm{L})$ established by FAO paper 29 and RD 1620/2007. Concentration of $\mathrm{Mg}^{2+}$ in RW exceeded 9 times the limit 
value of $60 \mathrm{mg} / \mathrm{L}$, while LW only once presented value of $\mathrm{Mg}^{2+}$ a little higher than the limit value of $60 \mathrm{mg} / \mathrm{L}$. The sulfate $\left(\mathrm{SO}_{4}^{2-}\right)$ concentrations of $\mathrm{RW}$ and LW were under the limit value of $960 \mathrm{mg} / \mathrm{L}$ along the entire period of this study [21].

\subsection{Concentration in RW and LW of Essential Minerals for Plant Nutrition}

Plants require for complete their life cycle: nitrogen, phosphorous, and potassium as primary nutrients. Normally these minerals are absorbed by plant roots from the soil solution as anionic nitrate $\left(\mathrm{NO}_{3}^{-}\right)$or cation ammonium $\left(\mathrm{NH}_{4}^{+}\right)$, and as oxyanion phosphate $\left(\mathrm{PO}_{4}^{3-}\right)$. Potassium, presented as free cations $\left(\mathrm{K}^{+}\right)$is absorbed by plant as ionic form.

The concentrations of total N, P and K in RW and LW are shown in Figures 7 (a)-(c), respectively. Considering that one of the main aims of the MBR plant is to keep N, P and K content to use them for crop fertilization instead of commercial fertilizer, no limits for comparison were established. Hoagland $1 / 4$ strength nutrient solution was chosen for irrigation as it satisfies the nutritional needs of tomato, avocado and mango crops. The average content of $\mathrm{N}$ in RW was about $36.4 \mathrm{mg} / \mathrm{L}$ which is $72 \%$ the amount required for the Hoagland $1 / 4$ strength fertigation solution. Similarly, the amount required for the Hoagland $1 / 4$ strength is $7.74 \mathrm{mg} / \mathrm{L}$ for $\mathrm{P}, 64.51 \mathrm{mg} / \mathrm{L}$ for $\mathrm{K}$, RW can satisfy $65 \%$ and $46 \%$ of $\mathrm{P}$ and $\mathrm{K}$ needs, respectively.

\subsection{Trace Elements and Heavy Metals in RW and LW}

Assessment of trace elements and heavy metals developed in this study includes the measurements of the concentration of boron (B), arsenic (As), iron (Fe), zinc $(\mathrm{Zn})$, molybdenum $(\mathrm{Mo})$, manganese $(\mathrm{Mn})$, and copper $(\mathrm{Cu})$, in both $\mathrm{RW}$ and LW.

The limit values for B established by WHO Guidelines [21] and the Spanish legislation (RD 1620/2007) [17] are $3 \mathrm{mg} / \mathrm{L}$ and $0.5 \mathrm{mg} / \mathrm{L}$, respectively. The concentrations of $B$ in both water types were below these limits (Figure 8(a)). The threshold value for As content proposed by RD 1620/2007 is $0.1 \mathrm{mg} / \mathrm{L}$. During the time-period of this study, the concentration of As in the RW and in the LW did not exceed this limit value (Figure 8(b)).

On the days when the two water sources were analyzed, the content of Fe was below the limit value of $0.5 \mathrm{mg} / \mathrm{L}$ stated by the current legislation. The contents of $\mathrm{Zn}$ and Mo in LW and RW were also under the limit values established by the Spanish RD 1620/2007 which are $2 \mathrm{mg} / \mathrm{L}$ and $0.01 \mathrm{mg} / \mathrm{L}$ for $\mathrm{Zn}$ and Mo, respectively.

The limit values for $\mathrm{Mn}$ for safe water reuse is $0.2 \mathrm{mg} / \mathrm{L}$. Presence of $\mathrm{Mn}$ in RW and LW was under this limit value $(0.2 \mathrm{mg} / \mathrm{L})$ during the whole period of this study.

On several occasions $\mathrm{Cu}$ was recorded in high concentration in both water types comparing to the limit value of $0.2 \mathrm{mg} / \mathrm{L}$ established by RD 1620/2007. RW 


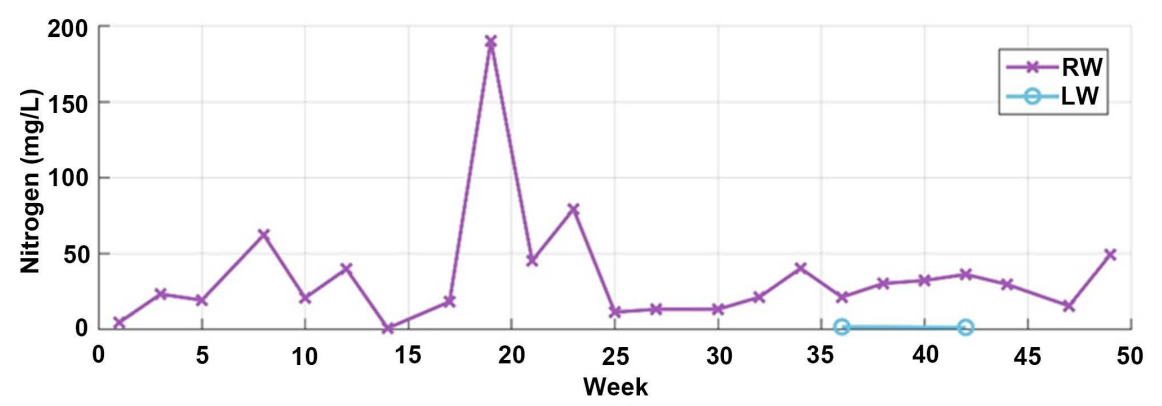

(a)

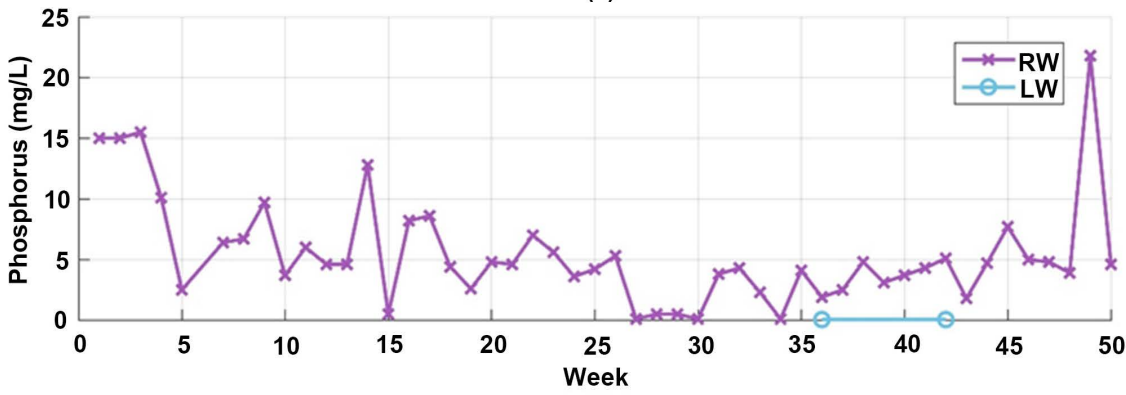

(b)

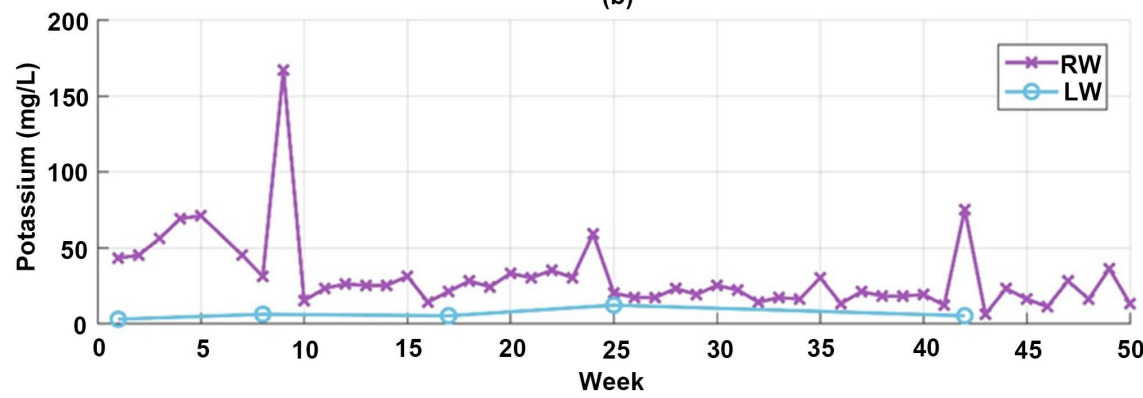

(c)

Figure 7. Time evolution of nitrogen (a), phosphorous (b) and potassium (c) recorded in fresh local water (LW) from Algarrobo River and in reclaimed urban water (RW) from the MBR plant.

exceeded this limit 4 times: in the weeks 12 and 14 (October 2017) with $10 \mathrm{mg} / \mathrm{L}$ content of $\mathrm{Cu}$, in the week 21 (December, 2017) with $21 \mathrm{mg} / \mathrm{L}$ of $\mathrm{Cu}$ and in the week 47 (June 2018) when the recorded content of $\mathrm{Cu}$ was $44 \mathrm{mg} / \mathrm{L}$. LW also contained $\mathrm{Cu}$ out of the limit in the week 12 (October, 2017), reaching a value of $10 \mathrm{mg} / \mathrm{L}$. These high concentrations of $\mathrm{Cu}$ in both types of water are probably related to the water pipes of sewage system. Old houses in the Algarrobo municipality still maintain pipes made of $\mathrm{Cu}$ for municipal sewage system, which have a tendency for leaching up $\mathrm{Cu}$ and lead it to the water. The dates in which the highest levels of $\mathrm{Cu}$ were found coincide with periods of seasonal vacation, during the rest of the year most of these houses are not inhabited.

\subsection{Efficiency of the MBR Plant}

Due to the introduction of new technologies, along with an increase in demand, the use of membranes has become a cost-effective solution to regenerate wastewaters. However, choosing the right membranes meeting the needs of 


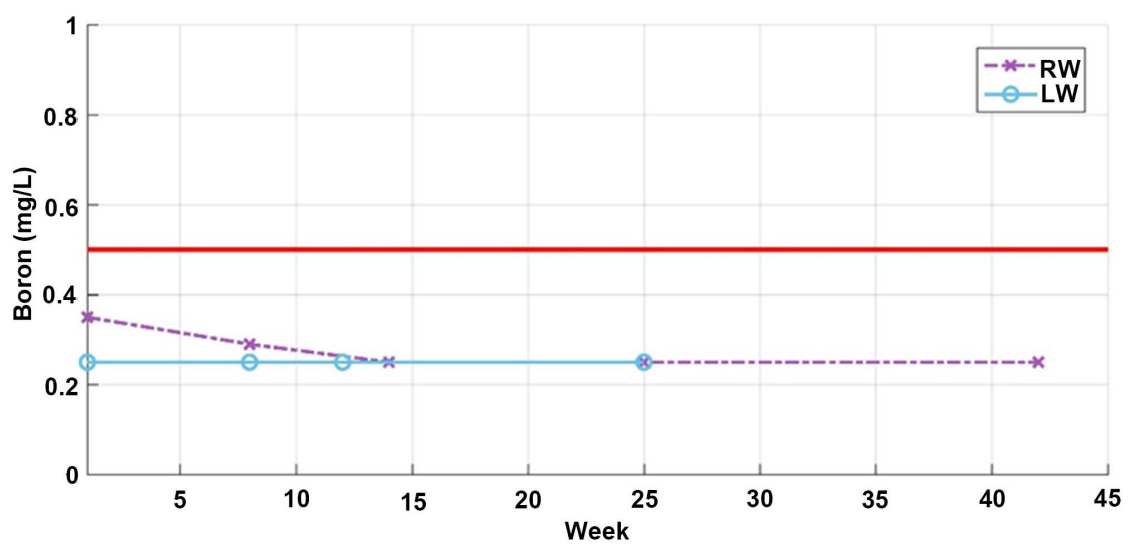

(a)

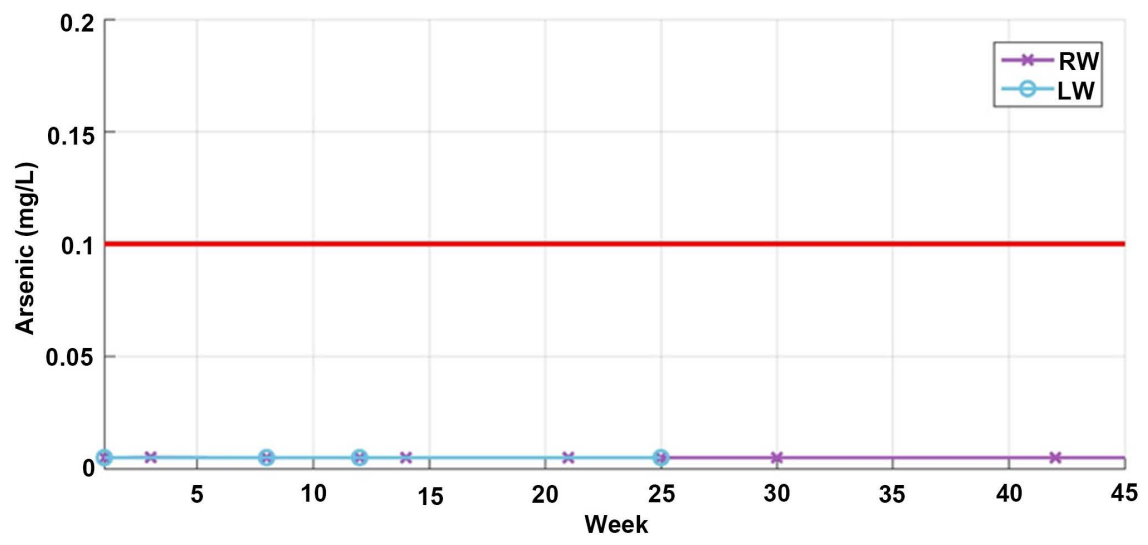

(b)

Figure 8. Time evolution of boron (B) and arsenic (As) contents recorded in fresh local water from Algarrobo River (LW, blue line), and in reclaimed urban water (RW) from MBR plant (violet line).Red lines show the limit values stated by the current Spanish legislation RD 1620/2007, and by the European Directive 91/271/EEC.

water characteristics is of extreme importance. This is why laboratory analysis and onsite pilot testing must be often conducted to ensure proper wastewater treatment. The constant measurement of water quality parameters carried out in the MBR plant during the present study provides valuable information, which is a critical step toward ensuring water quality and safety throughout the distribution in the irrigation system.

Removal efficiency of the MBR plant was calculated by applying Equation (2), where average concentration of parameter for influent and effluent wastewater is known.

$$
\text { removal efficiency }=\frac{\text { influent }\left(\frac{\mathrm{mg}}{\mathrm{L}}\right)-\text { effluent }\left(\frac{\mathrm{mg}}{\mathrm{L}}\right)}{\operatorname{influent}\left(\frac{\mathrm{mg}}{\mathrm{L}}\right)} \times 100 \%
$$

The recovery rate of nitrogen from the municipal wastewater was $72 \%$, while that of phosphorous was $63 \%$. Unfortunately, it was not possible to calculate the removal efficiency for potassium, because we did not have information about the 
content of potassium in wastewater before treatment with the MBR, without these data the calculations cannot be done.

\section{Conclusions}

From this study it appears that it is possible, through ultrafiltration using membrane technology, to treat in a single operation urban wastewater in order to supply a good quality of water for irrigation purposes. The analyses of water from the MBR plant have proved that this technology is efficient enough for removal of microbiological pollutants, inorganic compounds, some trace elements and heavy metals. The assessment of RW shows that the evaluated parameters of water-quality are within the range of values stated by Spanish legislation (RD 1620/2007), EU Directive (91/271/EEC) and with FAO and WHO guidelines for secure use of water.

This study is the first carried out in Málaga province. Recorded data show that the reclaimed urban wastewater by the MBR plant in Algarrobo municipality is good for irrigation. This RW has low heavy metals content and high levels of $\mathrm{N}$, $\mathrm{P}$ and $\mathrm{K}$. However, more studies are needed in order to know how water quality varies over time and how it affects the soils and main crops in the area. This information is essential to ensure the sustainable application of RW and to develop appropriate management practices as dilution of RW with conventional water resources.

\section{Acknowledgements}

This study was supported by the Horizon 2020 EU program, as a part of the RichWater project, FTIPilot-1-2015 GA number 691402. "First application and market introduction of combined wastewater treatment and reuse technology for agricultural purposes". The authors wish to express their gratitude to Alberto Pérez-Gil, mayor of Algarrobo, and José Manuel Gil-Segovia, president of the community of irrigators of Algarrobo for their enthusiasm and help in obtaining the permissions necessary for the development of this project. Authors are thankful to Francisco Bazaga-Calderón for the English correction of the manuscript.

\section{Conflicts of Interest}

The authors declare no conflicts of interest regarding the publication of this paper.

\section{References}

[1] Pretty J. and Bharucha Z.P. (2014) Sustainable Intensification in Agricultural Systems. Annals of Botany, 114, 1571-1596. https://doi.org/10.1093/aob/mcu205

[2] European Commission (2018) Water Is Too Precious to Waste. European Commission. http://ec.europa.eu/environment/water/pdf/water_reuse_factsheet_en.pdf

[3] Furumai, H. (2008) Rainwater and Reclaimed Wastewater for Sustainable Urban 
Water Use. Physics and Chemistry of the Earth, 33, 340-346.

https://doi.org/10.1016/j.pce.2008.02.029

[4] Alonso, M.C., Dionisio, L.P.C., Bosch, A., Pereira de Moura, B.S., García-Rosado, E. and Borrego, J.J. (2006) Microbiological Quality of Reclaimed Water Used for Golf Courses' Irrigation. Water Science and Technology, 54, 109-117. https://doi.org/10.2166/wst.2006.456

[5] Oron, G., Armon, R., Mandelbaum, R., Manor, Y., Campos, C., Gillerman, L., Salgot, M., Gerba, C., Klein, I. and Enriquez, C. (2001) Secondary Wastewater Disposal for Crop Irrigation with Minimal Risks. Water Science and Technology, 43, 139-146. https://doi.org/10.2166/wst.2001.0603

[6] Santafé-Moros, A., Gozálvez-Zafrilla, J.M. and Lora-García, J. (2005) Performance of Commercial Nanofiltration Membranes in the Removal of Nitrate Ions. Desalination, 185, 281-287. https://doi.org/10.1016/j.desal.2005.02.080

[7] Nghiem, L.D. and Hawkes, S. (2009) Effects of Membrane Fouling on the Nanofiltration of Trace Organic Contaminants. Desalination, 236, 273-281. https://doi.org/10.1016/j.desal.2007.10.077

[8] Fazal, S., Zhang, B., Zhong, Z., Gao, L. and Chen, X. (2015) Industrial Wastewater Treatment by Using MBR (Membrane Bioreactor) Review Study. Journal of Environmental Protection, 6, 584-598. https://doi.org/10.4236/jep.2015.66053

[9] Diop, S.N., Diallo, M.A., Diawara, C.K. and Cot, D. (2011) Intrinsic Properties and Performances of NF270 and XLE Membranes for Water Filtration. Water Science \& Technology. Water Supply, 11, 186-193. https://doi.org/10.2166/ws.2011.024

[10] Diawara, C.K. (2008) Nanofiltration Process Efficiency in Water Desalination. Separation \& Purification Reviews, 37, 303-325. https://doi.org/10.1080/15422110802228770

[11] Rolim, J., Teixeira, J.L., Catalão, J. and Shahidian, S. (2017) The Impacts of Climate Change on Irrigated Agriculture in Southern Portugal. Irrigation and Drainage, 66, 3-18. https://doi.org/10.1002/ird.1996

[12] Vogeler, I. (2009) Effect of Long-Term Wastewater Application on Physical Soil Properties. Water, Air, and Soil Pollution, 196, 385-392.

https://doi.org/10.1007/s11270-008-9785-x

[13] Romero-Aranda, R., Moya, J.L., Tadeo, F.R., Legaz, F., Primo-Millo, E. and Talón, M. (1998) Physiological and Anatomical Disturbances Induced by Chloride Salts in Sensitive and Tolerant Citrus: Beneficial and Detrimental Effects of Cations. Plant, Cell and Environment, 21, 1243-1253. https://doi.org/10.1046/j.1365-3040.1998.00349.x

[14] Romero-Aranda, R., Soria, T. and Cuartero, J. (2001) Tomato Plant-Water Uptake and Plant-Water Relationships under Saline Growth Conditions. Plant Science, 160, 265-272. https://doi.org/10.1016/S0168-9452(00)00388-5

[15] Taigbenu, E. and Ncube, M. (2005) Reclaimed Water as an Alternative Source of Water for the City of Bulawayo, Zimbabwe. Physics and Chemistry of the Earth, Parts $A / B / C, 30,762-766$. https://doi.org/10.1016/j.pce.2005.08.017

[16] Newterra (2018) Cassette Filter-MicroClear. https://www.microclear.de/en/products/cassette-filter/

[17] RD Real Decreto 1620/2007 (2007) El Régimen Jurídico de la Reutilización de las Aguas Depuradas. BOE, 294, 50639-50661. https://www.boe.es/boe/dias/2007/12/08/pdfs/A50639-50661.pdf

[18] European Council Directive 91/271/EEC, Annex I (1991) Concerning Urban Waste-Water 
Treatment. Official Journal of the European Communities, L135, 40-52. https://eur-lex.europa.eu/legal-content/EN/TXT/PDF/?uri=CELEX:31991L0271\&fr om=en

[19] US Environmental Protection Agency Method 1604 (2002) Total Coliforms and Escherichia coli in Water by Membrane Filtration Using a Simultaneous Detection Technique (MI Medium). Rept. Mo. EPA 821-R-02-024, Environmental Protection Agency, Washington DC. http://www.epa.gov/microbes/documents/1604sp02.pdf

[20] Silva, G.S., Santos, J.M. and Ferraz, S. (1988) Novo Método de Coloraçao de Ootecas de Meloidogyne spp. Nematologia Brasilense, 12, 6-7.

[21] WHO (2006) Guidelines for the Safe Use of Wastewater, Excreta and Greywater. Volume 2, Wastewater Use in Agriculture. World Health Organization, Geneva. https://www.who.int/water_sanitation_health/publications/gsuweg2/en/

[22] Yeo A.R. and Flower T.J. (2007) Plant Solute Transport. Blackwell Publishing Ltd., New Delhi. https://doi.org/10.1002/9780470988862

[23] US Environmental Protection Agency (2004) Guideline for Water Reuse. EPA 645-R-04-108, Environmental Protection Agency, Washinong DC. http://water.epa.gov/aboutow/owm/upload/Water-Reuse-Guidelines-625r04108.pff

[24] Hu, K., Huang, Y., Li, H., Li, B., Chen, D. and White, R.E. (2005) Spatial Variability of Shallow Groundwater Levels, Electrical Conductivity and Nitrate Concentration and Risk Assessment of Nitrate Contamination in North China Plain. Environmental International Journal, 31, 896-903. https://doi.org/10.1016/j.envint.2005.05.028

[25] Romero-Aranda, R., Soria, T. and Cuartero, J. (2002) Greenhouse Mist Improves Yield of Tomato Plants Grown under Saline Conditions. Journal of the American Society for Horticultural Science, 127, 644-648. http://journal.ashspublications.org/content/127/4/644.abstract

[26] Romero-Aranda, R., Jurado, O. and Cuartero, J. (2006) Silicon Alleviates the Deleterious Salt Effect on Tomato Plant Growth by Improving Plant Water Status. Journal of Plant Physiology, 163, 847-855. https://doi.org/10.1016/j.jplph.2005.05.010

[27] Ruiz-Baena, N. (2008) Water Quality for Irrigation. UNESCO Catalogue. Agricultural Engineering 310200.

https://www.juntadeandalucia.es/agriculturaypesca/ifapa/web/contenidoAlf?id=379 b1c81-3e50-4d39-b0e1-fd677fd69822

[28] Ruiz-Baena, N. (2008) The Salinity of Irrigation Water and Soil. UNESCO catalogue. Agricultural Engineering 310200.

https://www.juntadeandalucia.es/agriculturaypesca/ifapa/web/contenidoAlf?id=f06 45953-09e7-4b60-8d40-6b69c528a2f8

[29] Ayers, R.S. and Westcot, D.W. (1985) Water Quality for Agriculture. FAO Irrigation and Drainage Paper 29. Food and Agriculture Organization of the United Nations, Rome. http://www.fao.org/docrep/003/T0234E/T0234E00.htm 